IZA DP No. 6671

How Are Firms Affected by the Crisis and How Do They React?

Niels Westergård-Nielsen

Ioana Neamtu

June 2012 


\title{
How Are Firms Affected by the Crisis and How Do They React?
}

\author{
Niels Westergård-Nielsen \\ $C C P$, Aarhus University \\ and IZA \\ loana Neamtu \\ $C C P$, Aarhus University \\ Discussion Paper No. 6671 \\ June 2012 \\ IZA \\ P.O. Box 7240 \\ 53072 Bonn \\ Germany \\ Phone: +49-228-3894-0 \\ Fax: +49-228-3894-180 \\ E-mail: iza@iza.org
}

\begin{abstract}
Any opinions expressed here are those of the author(s) and not those of IZA. Research published in this series may include views on policy, but the institute itself takes no institutional policy positions.

The Institute for the Study of Labor (IZA) in Bonn is a local and virtual international research center and a place of communication between science, politics and business. IZA is an independent nonprofit organization supported by Deutsche Post Foundation. The center is associated with the University of Bonn and offers a stimulating research environment through its international network, workshops and conferences, data service, project support, research visits and doctoral program. IZA engages in (i) original and internationally competitive research in all fields of labor economics, (ii) development of policy concepts, and (iii) dissemination of research results and concepts to the interested public.
\end{abstract}

IZA Discussion Papers often represent preliminary work and are circulated to encourage discussion. Citation of such a paper should account for its provisional character. A revised version may be available directly from the author. 


\section{ABSTRACT}

\section{How Are Firms Affected by the Crisis and How Do They React?*}

The recession started in 2008 constituted a massive shock to consumers and most firms all over the Western World. Firms were hit on their sales and finances. However, little is known on how badly they were hit and how they coped with the difficulties. This paper gives a rare and fairly early glimpse on how private Danish firms were hit and how they adjusted in order to survive the crisis. The first phase of the recession led to the largest loss of jobs since the oil crisis in Denmark. Four years into the recession we see that larger firms are gradually creating jobs again, although the overall job growth is still negative (Statistics Denmark, 2012). Consequently we present an assessment of factors that have been important in explaining why some firms have been able to recreate jobs and others have not. Especially, we point at the critical role of access to credit in creating and destroying jobs. The paper is based on a survey run on all Danish firms with more than 20 employees in November and December 2011.

JEL Classification: J62, D22, E32, J33

Keywords: crisis, impact on firms, credit constraints, job growth and destruction, survey

Corresponding author:

Niels Westergård-Nielsen

Department of Economics

Aarhus School of Business and Social Sciences

Frichshuset

Hermodsvej 22

DK 8230 Aabyhøj

Denmark

E-mail: nwn@asb.dk

\footnotetext{
* The authors wish to thank Tor Eriksson, Niels H. Bjørn, Anders Frederiksen and Jesper Rangvid for comments on an earlier version of this paper. The paper has also benefited from a presentation in the National Bank of Denmark.
} 


\section{Introduction}

The recession started in 2008 constitutes a massive shock to consumers and most firms. Firms were hit on their sales and finances. However, little is known on how badly they were hit and how they coped with the difficulties. This paper gives a rare and fairly early glimpse at how private Danish firms were hit and how they adjusted in order to survive the crisis. In Denmark, the first phase of the recession led to the largest loss of jobs since the oil crisis. Four years into the recession we see that larger firms are gradually creating jobs again, although the overall job growth is still negative (Statistics Denmark, 2012). Consequently, we present an assessment of factors that have been important in explaining why some firms have been able to recreate jobs and others have not. We especially point to the role of the financial sector in creating and destroying jobs.

This paper builds on a survey run on a random sample ${ }^{1}$ of Danish firms in late 2011. Parts of the survey's questions are intentionally almost identical to those found in a survey run by ECB in 2009, although the sample in Denmark is larger and also has extra questions on job creation and destruction, for example. Because of the close relationship with the ECB survey which covered a number of European countries except Denmark, we are able to benchmark some of the Danish results.

Firms receive different macro economic and micro economic shocks all the time. The macro economic shocks come from general changes in demand, while the micro economic shocks come from other firms in the supply chain, local labour market or the production process. Each time a shock is received, the firm has to find a way to react to the different impulses. Its reactions will be constrained by overall rules, institutions and its own flexibility with respect to contracts, employees, customers and suppliers as well as financial possibilities.

Micro economic theory predicts different responses depending on the market situation of the firm: if a firm has a decreasing demand curve for its products and is experiencing a drop in sales, theory suggests that it will firstly cut production and secondly cut costs. The first action may involve closing down production lines, laying

${ }^{1}$ Given that we are surveying the firms 3 years after the crisis started, a number of firms have already closed down which means that we are getting a bias because we are only surveying firms that were able to survive the initial shock of the crisis. 
off production workers and/or reducing staff. Depending on the possibilities of renegotiating wage contracts, the second action may involve cutbacks in wages. In Denmark it is reasonably easy to lay off employees because of relatively weak job protection (OECD, 2004). Among employees, it is relatively easy to lay off blue-collar workers, while it is more costly to lay off salaried employees because of tenure related notice periods. Therefore, one would expect that firms react to a negative demand shock by laying off workers first and later laying off salaried employees. Another possibility is to renegotiate wages. There are two options in this case. One option is to renegotiate wages that are determined by contracts with the Trade Unions, which are mostly spread among blue-collar workers. The other option is to renegotiate the wage allowances consisting of bonuses and options. In many cases, these will adjust on their own as a consequence of the lower sales. While renegotiating a contract is extremely rare, adjusting bonuses is probably more frequent. The chosen strategy will depend on the possibilities rendered by the type of contracts signed with the employees. Nevertheless, it is an empirical question that needs an empirical answer.

Yet another response to a drop in sales is, of course, to lower prices and accept a smaller margin in the short run, to compensate for the reduction of demand. This requires that the firm has enough economic strength to make this adjustment.

Firms under full competition will have a more difficult situation. They will experience an immediate price drop on the market which means that they will not be able to cover all their fixed costs. This will motivate those with the highest costs to leave business relatively quickly, and allow others to survive. Cost savings will then be their only way to survive.

Considering this, we investigate, in the first part of our paper, the responses of Danish firms to the crisis and analyse the determinants of the crisis. In the second part of the paper we investigate the effects of the financial and demand problems on the growth of the firm, looking at job creation and destruction. 


\section{Literature}

The Wage Dynamics Network (WDN) organized by the European Central Bank (ECB) ran a survey in 2009 in a number of E.U. countries ${ }^{2}$. The purpose of that survey was to get an idea of how firms in member countries were affected and how they reacted to the challenges of the crisis.

The ECB survey has been used in a number of papers investigating different aspects of the crisis; whether to analyse the mechanisms of cost reduction adjustments to the crisis (e.g. Fabiani et al., 2011) or the price and wage adjustment mechanisms to shocks (Bertola et al. 2010; Druant et al., 2010).

Fabiani et al., 2011 report the intensity and nature of the initial shocks experienced by the firms and their reactions, given the different constraints of the firm and the national labour market regulations. Using country employment weighted means, it is demonstrated that there is a relationship between the GDP decline and the negative demand and credit shock. This provides a reassuring connection between the experience at the firm level and the national levels.

Similarly, Bertola et al., 2010, focus, in particular, on the impact of competition conditioned on the way firms are hit by the shock and on how they adjust to the crisis. Generally, they find that a significant but small proportion of the variation across countries and firms in adjustment strategies may be explained by structural and institutional features.

In the following sections, we will try to benchmark some of the Danish findings with the results of the above mentioned papers.

${ }^{2}$ Austria, Belgium, Czech Republic, Estonia, France, Italy, Luxemburg, Netherlands, Poland, Spain. 


\section{The survey data}

The questions in our survey have been designed to mimic as closely as possible the questions in the 2009 ECB survey. Since this is the third ECB survey run since 2007, it has a set of background variables in common with the previous ones, and since we do not have prior and similar information for Denmark, the comparison will have its short-comings. Part of these will be overcome in the future by adding financial background data from Danish register data as soon as these will be available.

Questions regarding the types and intensity of the crisis shocks and the types of adjustments made by the firms were added to a larger survey on wages, bonuses and other HR related issues. Therefore, it was addressed to the person responsible for personnel according to a register created by Statistics Denmark. The sample for the survey includes:

1. All firms with more than 20 employees from the Manufacturing industries.

2. Other private firms are sampled including

a. All firms with 100 and more employees

b. Around $60 \%$ of the firms with 50 to 99 employees .

c. Less than $20 \%$ of firms with less than 50 employees, where the sampling percentage of firms included is decreasing with the number of employees.

This type of sampling is in line with the sampling frame used by Statistics Denmark for business statistics ${ }^{3}$.

Statistics Denmark administered the survey and sent it to 3941 firms in November 2011. We received responses from 1961 firms. The response rates for different size groups and industries are reported in the Appendix.

The overall response rate is $49.8 \%$. $28.4 \%$ of the selected firms were not found or did not respond, while18.5\% rejected to answer the questions.

Overall, we have a population of responses of $23.6 \%$ of all firms larger than 20 employees. Due to the sampling frame, we have more responses from the Manufacturing industry, where the coverage is $49.3 \%$ for firms with more than 20

${ }^{3}$ See Appendix for details on the sampling frame and the response rates. 
employees. Our survey covers about $50 \%$ of all larger companies with more than 50 employees and a smaller proportion of the smaller firms.

\section{Affected and by how much?}

The first important question in the survey is whether or not the surveyed firm has been affected by the crisis and whether it was negatively or positively affected.

75.9\% of the surveyed firms answered affirmatively to the first question. $71.5 \%$ of them have been negatively affected and only $4.4 \%$ of them state that they have been positively affected by the crisis. These percentages do not vary grossly between industries, although there are some smaller differences.

Table 1 and 2 show how firms have been affected, divided by industry and size.

Table 1: Percentage of firms affected by the crisis, by industry

\begin{tabular}{l|ccccc|c}
$\begin{array}{c}\text { Affected by } \\
\text { the crisis (\%) }\end{array}$ & Manufacturing & Construction & Trade & Transport & Services & Total \\
\hline Affected & 75.4 & 78.7 & 83.3 & 74.5 & 70.7 & 75.9 \\
Negatively & 72.1 & 76.2 & 78.7 & 66.0 & 64.9 & 71.5 \\
Positively & 3.4 & 2.5 & 4.6 & 8.5 & 5.7 & 4.4 \\
$\begin{array}{l}\text { Not affected } \\
\text { Did not }\end{array}$ & 23.6 & 19.7 & 16.4 & 24.8 & 26.1 & 22.8 \\
answer & 0.9 & 1.6 & 0.3 & 0.7 & 3.2 & 1.3 \\
\hline $\begin{array}{l}\text { Total } \\
\text { Number of }\end{array}$ & 100 & 100 & 100 & 100 & 100 & 100 \\
firms & 956 & 122 & 329 & 153 & 402 & 1962
\end{tabular}

Trade seems to be affected the most. This is followed by Construction and Manufacturing. Services and Transport are the least affected industries.

The negative wave of the crisis was felt by all size groups, but slightly more by companies with 30 to 39 employees. Very few (4.9\%) have enjoyed positive effects of the crisis. 
Table 2: Percentage of firms affected by the crisis, by firm size

\begin{tabular}{l|ccccc|c}
\multirow{2}{*}{ Affected by the crisis (\%) } & \multicolumn{5}{|c|}{ Firm size (group of employees) } & Total \\
& $20-29$ & $30-39$ & $40-49$ & $50-99$ & $100+$ & \\
\hline Affected & 74.2 & 78.7 & 75.3 & 76.3 & 75.6 & 75.9 \\
Negatively & 70.2 & 75.1 & 72.9 & 71.3 & 70.7 & 71.5 \\
Positively & 4.0 & 3.6 & 2.4 & 4.9 & 4.9 & 4.4 \\
Not affected & 25.2 & 21.3 & 23.5 & 22.6 & 22.0 & 22.8 \\
Did not answer & 0.6 & 0.0 & 1.2 & 1.2 & 2.4 & 1.3 \\
\hline Total & 100 & 100 & 100 & 100 & 100 & 100 \\
Number of firms & 329 & 225 & 166 & 607 & 635 & 1962
\end{tabular}

These results raise the question of which firm characteristics are more likely to expose the firm to the crisis. Consequently, we run a logit function of being affected. The explanatory variables are firm size and industry, the competitive situation (where we distinguish between many and few competitors), if there is a contract with flexibility of hours ${ }^{4}$, and the general wage contract conditions of the firm. The latter is measured by the existence of a collective contract with salaried employees and blue-collar workers, respectively. Finally, this has been interacted with the indicator of flexibility, which takes the value one if there is a collective contract between firm and union and if there is, at the same time, an agreement of flexible hours over the year.

The results in Table 3 show that small firms (30-39 employees) are significantly more negatively affected by the crisis than other size groups. Trade appears to be more frequently hit compared to Manufacturing and Construction, while Services and Transport are least frequently hit by the crisis. The competition matters as expected: firms with few competitors ${ }^{5}$ are the least hit. This means that the more monopolistic the market is, the less likely it is for the firm to be hit by the crisis. Hours flexibility (most likely introduced before the crisis) has a positive impact for salaried employees, but it has no impact for blue-collar workers. This is surprising since hours flexibility has been built into the majority of blue collar contracts by now. Yet, the hypothesis is that this flexibility option has not been used at all. Surprisingly, the combined effect shows that companies with hours flexibility and

\footnotetext{
${ }^{4}$ An increasing number of firms have an agreement with workers allowing for more or less hours than the normal 37 hours as long as the average over a period of 1 year or more is 37 hours. The proportion of firms covered by such an agreement was 77\% in 2008, DA, 2011.

5 Few competitors - dummy variable; equals 1 for firms with less than 5 competitors.
} 
collective contracts for salaried employees are more likely to be affected by the crisis.

Table 3: Probability of being negatively affected by the crisis, based on specific firm characteristics (marginal effect)

(1)

\begin{tabular}{|c|c|c|c|c|}
\hline & $\begin{array}{l}\text { Probability of } \\
\text { being affected }\end{array}$ & $\begin{array}{l}\text { Robust } \\
\text { Standard } \\
\text { error }\end{array}$ & $\begin{array}{l}\text { Probability of } \\
\text { being affected }\end{array}$ & $\begin{array}{l}\text { Robust } \\
\text { Standard } \\
\text { error }\end{array}$ \\
\hline \multicolumn{5}{|l|}{$\begin{array}{l}\text { Firm size (ref 20-29 } \\
\text { employees) }\end{array}$} \\
\hline 30-39 employees & 0.09 & 0.05 & 0.10 & 0.05 \\
\hline 40-49 employees & 0.04 & 0.05 & 0.06 & 0.06 \\
\hline 50-99 employees & 0.05 & 0.04 & 0.04 & 0.05 \\
\hline 100+employees & 0.04 & 0.05 & -0.03 & 0.06 \\
\hline \multicolumn{5}{|l|}{ Industry (ref Transport) } \\
\hline Manufacturing & 0.12 & 0.05 & 0.14 & 0.09 \\
\hline Construction & 0.12 & 0.07 & 0.18 & 0.11 \\
\hline Trade & 0.22 & 0.06 & 0.21 & 0.10 \\
\hline Services & 0.04 & 0.06 & 0.10 & 0.10 \\
\hline Few competitors & -0.07 & 0.03 & -0.10 & 0.06 \\
\hline Bonuses for managers & 0.00 & 0.03 & 0.05 & 0.06 \\
\hline $\begin{array}{l}\text { Bonuses for salaried } \\
\text { employees and workers }\end{array}$ & -0.05 & 0.03 & -0.14 & 0.07 \\
\hline Danish Company & 0.00 & 0.03 & -0.06 & 0.06 \\
\hline Hours flexibility & -0.04 & 0.06 & -0.13 & 0.09 \\
\hline $\begin{array}{l}\text { Collective contract for } \\
\text { Salaried workers }\end{array}$ & -0.07 & 0.04 & -0.15 & 0.06 \\
\hline Collective contract for workers & 0.07 & 0.05 & 0.10 & 0.07 \\
\hline $\begin{array}{l}\text { Hours flexibility and collective } \\
\text { contracts for salaried workers }\end{array}$ & 0.13 & 0.06 & 0.10 & 0.11 \\
\hline $\begin{array}{l}\text { Hours flexibility and collective } \\
\text { contracts for workers }\end{array}$ & -0.04 & 0.07 & -0.04 & 0.12 \\
\hline
\end{tabular}

Notes: bold indicates significant at $10 \%$ level. Specification (2) shows weighted results, using employment weights

Another issue is how strong the different companies are affected. Table 4 shows the answers given by the companies to this question. Such questions are always difficult to evaluate because of the subjective element and because different respondents may ascribe different meanings to the concepts. But it seems safe to say that few firms feel only marginally affected, while the majority of firms affected feel moderately to strongly affected. Furthermore, a small number of firms say that they are positively affected by the crisis. 
Table 4: Intensity of the crisis, as experienced by the affected firms

\begin{tabular}{l|ccc}
$\begin{array}{l}\text { Intensity of the crisis for the firms } \\
\text { affected (\%) }\end{array}$ & Negative & Positive & Total \\
\hline Marginally & 13.4 & 17.4 & 13.6 \\
Moderately & 48.8 & 50.0 & 48.9 \\
Strongly & 27.8 & 20.9 & 27.4 \\
Very strongly & 9.2 & 9.3 & 9.2 \\
Did not answer & 0.9 & 2.3 & 0.9 \\
\hline Total & 100 & 100 & 100 \\
Number of firms & 1403 & 86 & 1490
\end{tabular}

A further question is on which of the measured parameters they feel most strongly affected. Table 5 summarizes the results and shows that most of the affected firms have felt the reduction of demand as the largest obstacle. This does not mean that firms did not have any other problems (because the obstacles encountered are not mutually exclusive), but those were not as important as the demand reduction. For example, severe financial difficulties were experienced by less than $12 \%$ of all firms.

Table 5: Primary effects of the crisis, by type of shock experienced

\begin{tabular}{l|cccc}
$\begin{array}{l}\text { Effect of the } \\
\text { crisis }\end{array}$ & $\begin{array}{c}\text { Reduction in } \\
\text { demand }\end{array}$ & $\begin{array}{c}\text { Financial } \\
\text { difficulties }\end{array}$ & $\begin{array}{c}\text { Diff. in getting } \\
\text { customers to pay }\end{array}$ & $\begin{array}{c}\text { Difficulties in } \\
\text { supply }\end{array}$ \\
\hline Not affected & 70 & 86 & 87.1 & 94 \\
Affected & 29 & 11.3 & 11 & 4.1 \\
Did not answer & 1.1 & 2.7 & 1.9 & 1.9 \\
\hline Total & 100 & 100 & 100 & 100 \\
Number of firms & 1489 & 1489 & 1489 & 1489
\end{tabular}

It is useful to see how different industries experienced these shocks. The results are reported in Table 6. It seems that Manufacturing was affected the strongest by the reduction in demand and supply, while Transport had the biggest financial difficulties among all industries. 
Table 6: Primary effects of the crisis by type of shock experienced and by industry. Percentages of firms affected

\begin{tabular}{l|ccccc|c}
\multicolumn{1}{c|}{$(\%)$} & Manufacturing & Construction & Trade & Transport & Service & Total \\
\hline $\begin{array}{l}\text { Reduction in } \\
\text { demand }\end{array}$ & 31.5 & 22.9 & 27.0 & 27.2 & 27.5 & 29.0 \\
$\begin{array}{l}\text { Financial } \\
\text { difficulties }\end{array}$ & 13.0 & 11.5 & 7.3 & 15.8 & 8.8 & 11.3 \\
$\begin{array}{l}\text { Difficulties with } \\
\text { customers }\end{array}$ & 9.8 & 11.5 & 11.3 & 15.8 & 11.3 & 10.9 \\
$\begin{array}{l}\text { Difficulties in } \\
\text { supply }\end{array}$ & 6.7 & 0.0 & 2.9 & 0.0 & 1.8 & 4.1 \\
\hline $\begin{array}{l}\text { Number of } \\
\text { firms affected }\end{array}$ & 721 & 96 & 274 & 114 & 284 & 1489
\end{tabular}

A similar table (Table 7) shows that big and small firms are affected in almost the same way. However, it is remarkable that bigger firms are less affected by financial difficulties than smaller ones, probably because they have better access to bank loans.

Table 7: Effects of the crisis by type of shock experienced and firm size

\begin{tabular}{l|ccccc|c}
\multicolumn{1}{c|}{$(\%)$} & $\begin{array}{c}20-29 \\
\text { employees }\end{array}$ & $\begin{array}{c}30-39 \\
\text { employees }\end{array}$ & $\begin{array}{c}40-49 \\
\text { employees }\end{array}$ & $\begin{array}{c}50-99 \\
\text { employees }\end{array}$ & $\begin{array}{c}100+ \\
\text { employees }\end{array}$ & Total \\
\hline $\begin{array}{l}\text { Reduction in } \\
\text { demand }\end{array}$ & 30.3 & 32.2 & 35.2 & 27.2 & 27.3 & 29.0 \\
$\begin{array}{l}\text { Financial difficulties } \\
\text { Difficulties with }\end{array}$ & 16.0 & 14.7 & 11.2 & 11.2 & 7.7 & 11.3 \\
$\begin{array}{l}\text { customers } \\
\text { Difficulties in supply }\end{array}$ & 11.1 & 12.4 & 10.4 & 11.4 & 10.0 & 10.9 \\
\hline $\begin{array}{l}\text { Number of firms } \\
\text { affected }\end{array}$ & 24.9 & 6.2 & 5.6 & 3.0 & 3.5 & 4.1 \\
\hline
\end{tabular}

The analysis also shows that one shock does not come alone. It appears that many firms experience both demand and credit shocks at the same time. Table 8 compares the Danish experience with the results in the ECB survey. However, there is a common general concern that these numbers depend on the past volatility of the underlying variable, and this may differ across the sampled countries. This problem is stronger for the Danish survey because data was collected at a later point of time in the development of the crisis than the data in the ECB survey. Therefore, some firms in the Danish sample may have been able to counteract the shocks, while others may have gone out of the sample of firms with more than 20 employees due to job destruction or bankruptcy. Another issue is that the Danish survey only covers firms down to 20 employees, where the ECB-survey covers firms with more than 10 
employees. It should also be mentioned that the sample size of the Danish survey is bigger than that of the ECB survey.

With these precautions in mind, we believe it is safe to say that the demand shock in Denmark belongs to the lowest among the countries in Table 8. The same is the case for credit shocks. Another $3.96 \%$ have been affected both by demand and credit shocks. Denmark seems to experience an incidence close to the one in Austria. When we compare Manufacturing and Trade, we find that Denmark has experienced a far better situation compared to the average European country both with respect to demand and credit shocks. However, with respect to Market services, Denmark has been hit almost at the average European level.

Table 8: Incidence of strong demand and credit shocks. Weighted by size of firm.

\begin{tabular}{|c|c|c|c|}
\hline Country & Demand & Credit & Demand + Credit \\
\hline Denmark & 26.25 & 7.51 & 3.96 \\
\hline Austria & 29.5 & 14.5 & 5.4 \\
\hline Belgium & 43.6 & 18.3 & 13.8 \\
\hline Czech Republic & 53.4 & 26.9 & 18.8 \\
\hline Estonia & 80.6 & 39.8 & 34.4 \\
\hline Spain & 40.5 & 27.5 & 19.4 \\
\hline France & 35.6 & 10.3 & 5.6 \\
\hline Italy & 43.9 & 21.1 & 12.6 \\
\hline Netherlands & 38.3 & 20.7 & 10.9 \\
\hline Poland & 22.1 & 15.3 & 7.9 \\
\hline Total & 38.4 & 19.5 & 11.9 \\
\hline Euro area & 32.7 & 19.3 & 11.7 \\
\hline Non-euro area & 40.1 & 19.5 & 11.9 \\
\hline Manufacturing & 50.4 & 24 & 16.1 \\
\hline $\begin{array}{l}\text { Denmark } \\
\text { Manufacturing }\end{array}$ & 28.3 & 8.6 & 4.3 \\
\hline Trade & 30.7 & 19.2 & 10.5 \\
\hline Denmark Trade & 30.19 & 4.88 & 3.73 \\
\hline Market services & 26.9 & 13.4 & 7 \\
\hline $\begin{array}{l}\text { Denmark } \\
\text { Services }\end{array}$ & 23.56 & 10.43 & 3.96 \\
\hline
\end{tabular}

Source: Fabiani et al., 2010, and own results, weighted by size 


\section{Responses to the crisis}

The second part of the survey investigates how firms have reacted to the shocks.

\section{The reduction in demand}

Among the companies moderately or strongly affected by a reduction in demand, we asked what they have done in order to cope with the situation. The respondents could give more than one answer. The majority of firms say that they have reduced their costs compared to reducing prices, production and gross margins (profit), which were the other options. First of all, this shows that many firms are doing several things at the same time, but their efforts almost always involve lowering costs.

Table 9: Firms responses to the reduction in demand.

\begin{tabular}{l|cccc}
$\begin{array}{l}\text { Responses of } \\
\text { firms (\%) }\end{array}$ & $\begin{array}{c}\text { Reduction in } \\
\text { prices }\end{array}$ & $\begin{array}{c}\text { Reduction in } \\
\text { production }\end{array}$ & $\begin{array}{c}\text { Reduction in } \\
\text { gross margin }\end{array}$ & $\begin{array}{c}\text { Reduction } \\
\text { in costs }\end{array}$ \\
\hline Yes & 43.3 & 49.9 & 48.0 & 81.0 \\
No & 55.9 & 48.9 & 50.0 & 18.6 \\
Did not answer & 0.8 & 1.2 & 2.1 & 0.5 \\
\hline Total & 100.0 & 100.0 & 100.0 & 100.0 \\
Number of firms & 1061 & 1061 & 1061 & 1061 \\
affected & & &
\end{tabular}

The next question addresses how firms reduced costs. Table 10 shows that the majority of firms reduced employment. It is surprising that there are only small differences across industries. Very few companies say that they reduced wages or different types of bonus payments. It is somewhat surprising that the reduction of costs is so focused on reductions in employment and that there is so little use of the other flexibilities in wages, bonus payments and hours. It is especially surprising because the on-going decentralisation of wage bargaining in Denmark has opened up for much more flexibility with respect to these factors. However, this is not a specific Danish reaction because it has also been found for the other European countries (Fabiani et al., 2010). 
Table 10: Types of cost reduction strategies, by industry.

\begin{tabular}{l|ccccc|c}
$\begin{array}{l}\text { Cost reduction by } \\
\text { reducing (\%) }\end{array}$ & Manufacturing & Construction & Trade & Transport & Service & Total \\
\hline The basic wage & 2.0 & 1.6 & 0.0 & 4.0 & 0.5 & 1.5 \\
Bonuses & 1.4 & 7.8 & 0.5 & 4.0 & 1.6 & 1.9 \\
Employees & 58.3 & 51.6 & 59.2 & 52.0 & 63.5 & 58.5 \\
Hours worked & 2.6 & 0.0 & 1.5 & 9.3 & 1.1 & 2.4 \\
Other reductions & 35.3 & 37.5 & 38.3 & 30.7 & 33.3 & 35.3 \\
Did not answer & 0.4 & 1.6 & 0.5 & 0.0 & 0.0 & 0.4 \\
\hline Total & 100.0 & 100.0 & 100.0 & 100.0 & 100.0 & 100.0 \\
Number of firms & 501 & 64 & 196 & 75 & 189 & 1025 \\
affected & & & & & &
\end{tabular}

However, wages are not completely unaffected. Almost $40 \%$ of all firms in the survey indicate that they imposed a wage freeze, and another $10 \%$ say that they will do it. The differences across industries clearly reflect the degree of foreign competition as fewer Service and Transport firms say that they have frozen wages or intend to do so.

The percentage of employees affected by the wage freeze is quite big, $75.5 \%$, on average.

Table 11:Percentage of firms that have or will freeze wages as response to the crisis, by industry and the share of employees affected by this action.

\begin{tabular}{l|ccccc|c} 
Freeze salary (\%) & Manufacturing & Construction & Trade & Transport & Service & Total \\
\hline No & 43.9 & 44.3 & 44.9 & 53.9 & 57.0 & 47.5 \\
Yes, we have & 41.9 & 42.6 & 41.1 & 37.0 & 34.0 & 39.8 \\
Yes, we will & 11.8 & 9.8 & 11.4 & 9.1 & 6.6 & 10.2 \\
Did not answer & 2.7 & 3.3 & 2.3 & 0.0 & 2.4 & 2.4 \\
\hline Total & 100 & 100 & 100 & 100 & 100 & 100 \\
Number of firms & 956 & 122 & 329 & 153 & 402 & 1962 \\
\hline $\begin{array}{l}\text { Employees } \\
\text { affected by salary }\end{array}$ & 78.68 & 78.55 & 80.22 & 60.40 & 66.12 & 75.5 \\
freezing (\%) & & & & & &
\end{tabular}

In order to investigate which factors (firm characteristics) might influence the decision of freezing the salaries of the employees, we have estimated a logit function. Results are shown in Table 12, and it seems that the smallest firms have higher chances of freezing wages, compared to the bigger firms, while the type of industry does not have a determining role. What seems to matter is the effect of the crisis on the company and whether the company has been affected by it or not. Thus, the probability of freezing wages is significantly higher for companies that have been 
affected by the crisis, compared to those that declared themselves unaffected. Furthermore, it can be seen that negatively affected firms have higher probability of freezing wages than the ones positively affected by the crisis, which of course is not surprising. Work flexibility or type of contract does not seem to influence the wage freeze probability at all. Similarly, it is found that market competition has a negative impact. Specifically, the probability of freezing wages decreases in monopolistic markets.

Table 12: Logit results of firm characteristics on the probability of freezing wages. (marginal effects)

\begin{tabular}{|c|c|c|}
\hline & $\begin{array}{l}\text { Probability of } \\
\text { freezing wages }\end{array}$ & Robust Std. Err. \\
\hline \multicolumn{3}{|l|}{ Firm size (reference:20-29 employees) } \\
\hline 30-39 employees & -0.13 & 0.06 \\
\hline 40-49 employees & -0.04 & 0.06 \\
\hline 50-99 employees & -0.04 & 0.05 \\
\hline $100+$ employees & -0.15 & 0.06 \\
\hline \multicolumn{3}{|l|}{ Industry (reference Transport) } \\
\hline Manufacturing & 0.04 & 0.09 \\
\hline Construction & 0.01 & 0.11 \\
\hline Trade & -0.01 & 0.10 \\
\hline Services & -0.02 & 0.10 \\
\hline Revenue & 0.00 & 0.03 \\
\hline Negatively affected & 0.25 & 0.07 \\
\hline Positively affected & -0.09 & 0.16 \\
\hline Few competitors & -0.12 & 0.05 \\
\hline Danish company & -0.05 & 0.05 \\
\hline Net job creation & 0.00 & 0.00 \\
\hline Work flexibility & 0.05 & 0.10 \\
\hline $\begin{array}{l}\text { Collective contract for salaried } \\
\text { employees }\end{array}$ & 0.07 & 0.07 \\
\hline Collective contract for workers & -0.06 & 0.08 \\
\hline $\begin{array}{l}\text { Work flexibility and collective contract for } \\
\text { salaried workers }\end{array}$ & -0.07 & 0.11 \\
\hline $\begin{array}{l}\text { Work flexibility and collective contract for } \\
\text { workers }\end{array}$ & 0.02 & 0.12 \\
\hline Number of observations & 899 & \\
\hline Pseudo R2 & 0.09 & \\
\hline
\end{tabular}

Notes: bold indicates significant at $10 \%$; weighted results, using employment weights 


\section{The role of banks and credit}

Given that this crisis started out as a bank crisis, it is important to see to what extent credit constraints have dragged down firms. It appears that the shortage of funds is not one of the worst threats to the firms (only $21 \%$ of them have been affected) again, we have to remind ourselves that firms mostly affected by the shortage of finance probably have closed down at this point in the crisis.

In our sample, the number of firms saying that they have experienced a credit constraint is relatively small, as described in Table 13. It is impossible to say if this is a small or large increase in credit constraints, since we did not observe the firms before the crisis.

Table 13: The prevalence of credit constraints among the firms experiencing financial difficulties.

\begin{tabular}{l|ccccc|c}
$\begin{array}{l}\text { Firms } \\
\begin{array}{l}\text { experiencing } \\
\text { financial } \\
\text { difficulties (\%) }\end{array}\end{array}$ & $\begin{array}{c}\text { 20-29 } \\
\text { employees }\end{array}$ & $\begin{array}{c}30-39 \\
\text { employees }\end{array}$ & $\begin{array}{c}40-49 \\
\text { employees }\end{array}$ & $\begin{array}{c}50-99 \\
\text { employees }\end{array}$ & $\begin{array}{c}100+ \\
\text { employees }\end{array}$ & Total \\
\hline $\begin{array}{l}\text { Limited } \\
\text { access to } \\
\text { credit }\end{array}$ & 43.0 & 33.3 & 41.7 & 36.4 & 33.9 & 37.0 \\
$\begin{array}{l}\text { Problems } \\
\text { financing new } \\
\text { projects } \\
\text { Large }\end{array}$ & 62.8 & 73.3 & 58.3 & 58.5 & 41.1 & 56.4 \\
$\begin{array}{l}\text { borrowing } \\
\text { costs }\end{array}$ & 36.0 & 31.7 & 27.8 & 30.5 & 25.0 & 30.0 \\
\hline $\begin{array}{l}\text { Number of } \\
\text { firms affected }\end{array}$ & 86 & 60 & 36 & 118 & 124 & 424
\end{tabular}

The most important result is that a number of firms do not start new projects due to funding problems. In the next section, we will examine the overall impact of these constraints on job creation and destruction in order to investigate the costs to the economy. 


\section{Recent job market development}

For the analysis of the possible job loss we use the number of jobs created and destroyed by each firm in 2011, which is information obtained from a different part of the survey, that dealt specifically with the number of jobs created and/or destroyed in 2011. The jobs are divided within four personnel categories - top management, mid-level managers, salaried employees (white collar workers) and workers (blue collar workers).

We use these data to distinguish between expanding (positive net job creation) and contracting firms (negative net job creation).

\section{Job creation versus job destruction}

A firm is considered to be expanding if the number of jobs created is higher than the number of jobs destroyed. 6

$$
\text { Firm expanding }=\left\{\begin{array}{c}
1, \quad \text { if net job creation }>0 \\
0, \quad \text { otherwise }
\end{array}\right.
$$

Following the same logic, a firm is considered to be contracting if the number of jobs destroyed exceeds the number of jobs created.

$$
\text { Firm contraction }=\left\{\begin{array}{c}
1, \quad \text { if net job creation }<0 \\
0, \quad \text { otherwise }
\end{array}\right.
$$

Also, we consider a firm as having zero growth if net job creation is zero.

This definition does not account for the evolution of the different personnel categories within a company 7 , but the distinction between expanding and contracting is important because it allows us a better understanding of the "health" of the companies and a better overview of the direction of Danish economy. The expansion of a company indicates a positive evolution of the firm, a blossoming of the production generated either by an increase in the demand or by entering on a new market. The contraction of the firm indicates a restructuring of the company generated either by a reduction in demand or by the firm's decision to leave a certain

\footnotetext{
${ }^{6}$ This is in line with the typology of Lazear and Spletzer, 2011. A difference is that we look at job flows, and they look at worker flows with respect to hires and separations.

${ }^{7}$ A company may be destroying some types of jobs at the same time that it is categorized as expanding,. Thus, the number of blue collar jobs may go down but the the firm is characterized as expanding if the reduction is outnumbered by the increase in salaried employees.
} 
market. Financial difficulties generated by the crisis can also lead to contraction. We will further investigate these issues empirically in the second part of this section.

First, we analyse job growth for firms that are either expanding, have zero job growth or are contracting. Table 14 shows that the number of jobs created by the surveyed firms is higher than the number of jobs destroyed. However, this should not be taken as evidence that Denmark is now moving out of the crisis but as an indication that the surveyed firms are moving in the right direction and are on their way out of the crisis. However, Table 14 shows that some firms are still destroying jobs. Overall, our sample seems to have passed the trough of the crisis since job creation has been dominating destruction in 2011. Still, for the Manufacturing sector, the numbers of jobs created/destroyed reported by Statistics Denmark ${ }^{8}$ show a different picture in which job destruction dominates over job creation.

The differences between official statistics and our sample may be generated by a selection bias, because our sample consists of firms with more than 20 employees, and $50 \%$ of these firms are in Manufacturing. Furthermore, our sample may be biased towards the better firms because personnel managers in better companies may be more likely to respond to the survey than others, but this is probably not the main cause for the different outcomes. It is more likely that the difference is related to size of firms. The most likely scenario is that firms with less than 20 employees are responsible for the decline in jobs. This corresponds with our finding that the smallest firms in our sample are more seriously hit by the crisis 9 . Therefore, we can assess that the sampled firms are generally in a better shape than the average and smaller firm.

\footnotetext{
${ }^{8}$ See the Appendix for a better description.

${ }^{9}$ Since the published data from Statistics Denmark is not divided in size groups, we cannot confirm this hypothesis.
} 
Table 14: Job Creation and Destruction in 2011 in expanding and contracting firms in sample. (number of jobs)

\begin{tabular}{|c|c|c|c|c|c|c|}
\hline \multirow{2}{*}{ Industry } & \multicolumn{2}{|c|}{ Job creation } & \multirow[t]{2}{*}{ Zero growtl } & \multicolumn{2}{|c|}{ Job destruction } & \multirow{2}{*}{$\begin{array}{l}\text { Net job } \\
\text { creation }\end{array}$} \\
\hline & Expanding & Contracting & & Expanding & Contracting & \\
\hline Manufacturing & 7052 & 571 & 79 & 545 & 3375 & 3782 \\
\hline Construction & 1179 & 76 & 12 & 135 & 328 & 804 \\
\hline Trade & 2557 & 403 & 30 & 230 & 2573 & 187 \\
\hline Transport & 1951 & 37 & 11 & 191 & 828 & 980 \\
\hline Services & 3302 & 371 & 371 & 433 & 1854 & 1757 \\
\hline Total & 16041 & 1458 & 503 & 1534 & 8958 & 7510 \\
\hline
\end{tabular}

\section{Contracting or expanding?}

As shown in the previous chapter, the financial and economic crisis has caused firms to reduce costs and most of them responded by firing employees. We will now use the same information to investigate if credit constraints or other factors are correlated with the job destruction or expansion in 2011. Using a logit function, we have estimated the probability of a company restricting or expanding its activity and correspondingly, adjusting the number of employees.

In Table 15 we have controlled for firm size, industry, competition conditions and specific firm characteristics such as existence of a bonus system, collective contracts and flexible wages. The Large firm dummy variable equals one for firms with more than 50 employees, Bonus for employees is a dummy variable accounting for any type of bonus offered to the salaried workers and workers, and Low competition is a dummy variable equal to one for firms with less than 5 competitors. Furthermore, we have added variables for experienced difficulties with respect to demand and financial constraints.

We analyse two different scenarios; one where we compare contracting firms with expanding and zero growth firms, and one where we compare expanding firms with contracting and zero growth firms. We have also tried a multinomial logit specification with three separate outcomes. The results are not qualitatively different, but the first ones are easier to interpret. 
Table 15: The effects of the crisis on the decision of expanding or contraction. (marginal effect)

\begin{tabular}{l|cc|cc} 
& Contraction & Std. Err. & Expansion & Std. Err. \\
\hline Large firms & 0.03 & 0.03 & $\mathbf{0 . 0 7}$ & 0.04 \\
Manufacturing & -0.03 & 0.05 & -0.01 & 0.06 \\
Construction & -0.10 & 0.07 & 0.08 & 0.08 \\
Trade & 0.09 & 0.06 & -0.13 & 0.07 \\
Services & -0.07 & 0.06 & -0.10 & 0.07 \\
Bonuses for Top and Mid & -0.03 & 0.03 & $\mathbf{0 . 1 0}$ & 0.03 \\
Management & 0.02 & 0.03 & 0.03 & 0.03 \\
Bonuses for employees & -0.04 & 0.03 & 0.03 & 0.03 \\
Low competition & -0.06 & 0.07 & 0.06 & 0.07 \\
Flexible wages & 0.01 & 0.04 & -0.01 & 0.04 \\
Collective contract for salaried & 0.06 & 0.05 & -0.14 & 0.06 \\
workers & 0.00 & 0.06 & 0.01 & 0.06 \\
Collective contract for workers & 0.11 & 0.08 & -0.06 & 0.08 \\
Work flexibility and C.C for S & $\mathbf{0 . 0 9}$ & 0.04 & -0.06 & 0.04 \\
Work flexibility and C.C for W & -0.06 & 0.08 & 0.01 & 0.09 \\
Financial difficulties & $\mathbf{0 . 1 6}$ & 0.03 & -0.13 & 0.04 \\
Financial difficulties for large firms & 1115 & & 1115 & \\
Demand problems & 0.05 & & 0.06 &
\end{tabular}

Notes: bold indicates significance at $10 \%$-level.

Table 15 shows that problems with reduced demand in the beginning of the crisis will increase the likelihood that a firm contracts by 16\%, even in 2011, while financial difficulties increase this chance by $9 \%$. In the case of expanding firms, the coefficient to financial difficulties is negative but not significant, while the problems with demand will reduce the probability that a company expands by $13 \%$.

Moreover, large firms have higher chances of expanding than smaller firms. Firms in the Trade sector seem to have the lowest chances of expanding. Furthermore, it is also found that incentives for top management will increase the likelihood of an expansion.

It may be argued that financial constraints are a consequence of the demand problem as banks are more likely to reject financing in companies with demand problems. To limit this possible bias from demand problems in our results, we 
analysed the effects of financial difficulties on firms with different degrees of demand problems.

Furthermore, we divided financial difficulties into the underlying three questions: difficulties in getting finance for new projects, borrowing costs are too high, and limitations in existing credit and we ran separate regressions for each combination of levels of demand problems and types of financial difficulties, using the same explanatory variables as in Table 15 . The results are summarized in Table 16. The first column consists of those firms that had no demand problems at all, the second column of those who had moderate demand problems together with those with no demand problems, and finally for all firms irrespective of their level of demand problems. This is done for expanding and contracting firms separately, as in Table 15.

Table 16. Marginal effects of regressing job expansion and contraction on various measures of financial constraints on samples with different degrees of demand problems.

\begin{tabular}{|c|c|c|c|c|c|c|}
\hline \multirow[b]{2}{*}{ Demand problems } & \multicolumn{3}{|c|}{ Contraction } & \multicolumn{3}{|c|}{ Expansion } \\
\hline & None & $\begin{array}{l}\text { Moderate } \\
\text { or None }\end{array}$ & $\begin{array}{l}\text { Strong, } \\
\text { Moderate or } \\
\text { None }\end{array}$ & None & $\begin{array}{l}\text { Moderate } \\
\text { or None }\end{array}$ & $\begin{array}{l}\text { Strong, } \\
\text { Moderate } \\
\text { or None }\end{array}$ \\
\hline $\begin{array}{l}\text { Overall financial } \\
\text { difficulties }\end{array}$ & 0.22 & 0.10 & 0.12 & -0.05 & -0.08 & -0.10 \\
\hline Std dev. & 0.07 & 0.04 & 0.03 & 0.14 & 0.05 & 0.04 \\
\hline $\begin{array}{l}\text { Financing new } \\
\text { projects }\end{array}$ & 0.17 & 0.08 & 0.11 & 0.02 & -0.05 & -0.08 \\
\hline Std dev. & 0.09 & 0.04 & 0.04 & 0.15 & 0.05 & 0.04 \\
\hline $\begin{array}{l}\text { Borrowing costs are } \\
\text { too large }\end{array}$ & 0.21 & 0.16 & 0.27 & -0.09 & -0.18 & -0.21 \\
\hline Std dev. & 0.04 & 0.05 & 0.10 & 0.19 & 0.08 & 0.06 \\
\hline $\begin{array}{l}\text { Number of } \\
\text { observations }\end{array}$ & 339 & 868 & 1115 & 448 & 868 & 1115 \\
\hline
\end{tabular}

Note: Bolded coefficients are significant at $10 \%$

The first column of Table 16 shows that even firms having experienced no demand constraints have an increased probability of contraction due to financial difficulties. The next columns show that the marginal probability of contraction is also lower if they have been experiencing even moderate or strong demand problems together with financial difficulties. The type of financial difficulty seems to play almost no separate role, since the results are almost identical for difficulties financing new projects as for difficulties with borrowing costs. 
In the case of expanding firms, the probability of expansion is reduced by the existence of financial difficulties together with problems of demand. However, our results indicate a negative but not significant effect on the probability of expansion for the most restricted group of firms without demand problems. It is worth remarking that expansion is positively related to size, according to Table 15 , and from Table 13 we know that banking problem are less prevalent for large companies so it may be that size is a joint confounder that lowers the significance of the financial indicators on job creation.

Nevertheless, there is still the possibility that the negative correlation between job contraction and financial problems is due to a generally bad economic situation of the firm which will make the bank reject the credit application. It is, of course, hard to know which factors the bank will use for this decision. The most obvious candidates would be: total revenue, total profit (in levels or growth rates), equity or solvency of the previous year or a combination of these. In the next section we analyse the effects of the credit constraints on firms with a positive growth in revenue, in 2011, according to their own statement in the questionnaire. We use this proxy for a good/stable economic situation of the company under the hypothesis that a firm with growing revenue is less likely to be rejected by the bank.

Table 17: Marginal effects of regressing job expansion and contraction on various measures of financial constraints on samples with different degrees of demand problems under the condition that revenue is increasing in 2011.

\begin{tabular}{l|ccc|ccc|}
\multicolumn{1}{c|}{$\begin{array}{c}\text { Demand } \\
\text { problems }\end{array}$} & None & $\begin{array}{c}\text { Moderate } \\
\text { or None }\end{array}$ & $\begin{array}{c}\text { Strong, } \\
\text { Moderate or } \\
\text { None }\end{array}$ & None & $\begin{array}{c}\text { Expansion } \\
\text { or Non }\end{array}$ & $\begin{array}{c}\text { Strong, } \\
\text { Moderate or } \\
\text { None }\end{array}$ \\
\hline $\begin{array}{l}\text { Overall financial } \\
\text { difficulties }\end{array}$ & $\mathbf{0 . 2 9}$ & $\mathbf{0 . 1 1}$ & $\mathbf{0 . 1 0}$ & -0.13 & -0.08 & $-\mathbf{0 . 0 8}$ \\
$\begin{array}{l}\text { Std dev. } \\
\text { Financing new }\end{array}$ & 0.08 & 0.04 & 0.03 & 0.17 & 0.06 & 0.05 \\
projects & $\mathbf{0 . 3 2}$ & $\mathbf{0 . 1 1}$ & $\mathbf{0 . 1 1}$ & -0.10 & -0.06 & -0.06 \\
$\begin{array}{l}\text { Std dev. } \\
\text { Borrowing costs }\end{array}$ & 0.10 & 0.04 & 0.04 & 0.17 & 0.06 & 0.05 \\
$\begin{array}{l}\text { are too large } \\
\text { Std dev. }\end{array}$ & $\mathbf{0 . 3 0}$ & $\mathbf{0 . 0 9}$ & $\mathbf{0 . 1 5}$ & -0.15 & -0.17 & $-\mathbf{0 . 1 5}$ \\
\hline $\begin{array}{l}\text { Number of } \\
\text { observations }\end{array}$ & 0.10 & 0.07 & 0.05 & 0.22 & 0.09 & 0.07 \\
\hline
\end{tabular}


Table 17 shows that although this extra limitation lowers the number of observations, it does not change the coefficients very much compared to Table 16, where we just conditioned on various levels of demand constraints. All this points to the existence of a credit crunch in Denmark which affects even "healthy companies". Theoretically, the question remains whether it is a causal relation from credit to growth or it is the opposite relationship. However, since our results show that the relationship is maintained for the least likely situation, we believe that we have brought some evidence for a causal interpretation.

Furthermore, it is worth remarking that this result is obtained on firms that are generally doing much better with respect to job creation than the average Danish firm, suggesting even more severe financial difficulties for the average Danish company.

\section{Summary and conclusions}

This study contains analyses of a recent survey designed to investigate the evolution, experiences and reactions of Danish firms during the largest recession since the oil crisis in the 1970's. The first part of this study looked at the effects of the crisis on Danish firms, while the second part consisted of an analysis of the development of job creation and destruction in private sector firms.

The survey shows that almost all firms have been negatively affected by the crisis, although a small number of firms have benefitted from the crisis. The main way that firms have been affected has been by a decreasing demand for goods and services. The second most important way has been through a credit crunch. A large number of firms say that the lack of financial support for new projects has constrained their growth. These results may underestimate the real effects of credit constraints and demand reductions, especially for small firms, due to the possible bias in our survey. Comparing the survey with a similar survey conducted by the European Central Bank reveals that Danish firms have been hit by the economic crisis at a similar level as Austria, which is among the least affected countries in Europe in the ECB analysis. This result may, however, be biased by the fact that we have been surveying Danish firms 2 years later into the crisis compared to the European survey. This means that 
a number of firms have already been closed or have reduced their number of employees to 20 or less, making them non-participants in our survey.

In the second part of our study we look at the job creation and destruction behaviour of the surveyed firms in 2011. Our survey shows a more optimistic picture with a positive net creation of jobs in Danish firms, whereas Statistics Denmark still shows a negative development in 2011. This difference may be caused by the possible sampling bias in our survey.

Also, we show that smaller firms have a higher probability of becoming affected by the crisis while firms in a market with less competition have lower risk of being affected. Moreover, we show that financial and demand constraints trigger cost reduction that leads to a reduction of the number of employees and restructuring of the firms.

Finally, we find that firms in our sample are more likely to destroy jobs if they have credit problems. This coefficient remains significantly different from zero even when we only base our estimations on firms which did not have demand problems related to the crisis or when we restrict our estimates to companies with no demand problems and positive revenue growth in 2011. This indicates that firms, which have had no problems on the demand side and have no economic problems, are also constrained by the credit system.

A similar negative correlation of job creation and credit problems is only found for firms that also have demand problems so it is not possible to say that a credit constraint plays an independent role for job creation. Thus, for expanding firms it cannot be ruled out that banks do not constrain activities. However, it is found that expansion is higher for large firms and large firms do have less financial problems so it is hard to rule out a relationship between less expansion and finance problems.

Given the fact that we are investigating the large and probably better-fit firms, our results indicate an even larger and more serious credit problem for the smaller and less fortunate firms. 


\section{References}

Fabiani , S, A. Lamo,, J. Messina and T. Room, Firm Adjustment during times of Crisis, Centre for Economic Policy Research, paper at 7th ECB/CEPR Labour Market Workshop "Unemployment Developmenst After The Crisis", 2010

Bertola, G, A Dabusinskas, M. Hoeberichts, M. Izquierdo, C. Kwapil, J. Montornes, and D. Radowski, Price, Wage and Employment Response to Shocks: Evidence from the WDN Survey, 2010

Druant, M., S. Fabiani, G. Kezdi, A. Lamo, F. Martins, and R. Sabbatini, Firms'price and wage adjustment in Europe: survey evidence on nominal stickiness, Memo, 2010

Dansk Arbejdsgiverforening, Arbejdsmarkedsrapport 2011, DA 2012

Lazear, E and J. Spletzer, Hiring, Churn and the Business Cycle, Stanford 2011 


\section{Appendix}

\section{A. Sample description}

Table A1: Sampling Frame of survey; Percentage of firms sampled, by industry and number of employees.

\begin{tabular}{l|ccccc|c} 
Industry & $\begin{array}{c}20-29 \\
\text { employees }\end{array}$ & $\begin{array}{c}30-39 \\
\text { employees }\end{array}$ & $\begin{array}{c}40-49 \\
\text { employees }\end{array}$ & $\begin{array}{c}50-99 \\
\text { employees }\end{array}$ & $\begin{array}{c}100+ \\
\text { employees }\end{array}$ & Total \\
\hline Manufacturing & 99.1 & 99.1 & 100.0 & 99.6 & 99 & 99.3 \\
Construction & 5.6 & 13.8 & 19.3 & 63.2 & 100 & 25.0 \\
Trade & 7.6 & 9.4 & 18.4 & 61.9 & 98.9 & 30.0 \\
Transport & 3.9 & 11.8 & 10.6 & 62.0 & 98.7 & 32.4 \\
Services & 6.1 & 8.4 & 14.8 & 60.4 & 98.1 & 36.3 \\
\hline Total & 23.0 & 30.8 & 35.2 & 72.2 & 98.7 & 47.5
\end{tabular}

Table A2: Coverage rate of the survey, by industry and size group.

\begin{tabular}{l|ccccc|c} 
Industry & $\begin{array}{c}20-29 \\
\text { employees }\end{array}$ & $\begin{array}{c}30-39 \\
\text { employees }\end{array}$ & $\begin{array}{c}40-49 \\
\text { employees }\end{array}$ & $\begin{array}{c}50-99 \\
\text { employees }\end{array}$ & $\begin{array}{c}100+ \\
\text { employees }\end{array}$ & Total \\
\hline Manufacturing & 45.16 & 51.81 & 53.54 & 50.89 & 49.03 & 49.30 \\
Construction & 3.09 & 4.43 & 11.01 & 29.61 & 45.98 & 11.68 \\
Trade & 3.79 & 4.22 & 10.25 & 30.46 & 47.48 & 14.67 \\
Transport & 2.12 & 7.89 & 6.38 & 35.44 & 48.32 & 17.33 \\
Services & 3.33 & 4.35 & 7.42 & 35.11 & 43.90 & 18.27 \\
\hline Total & 10.84 & 15.68 & 18.99 & 37.90 & 46.82 & 23.63
\end{tabular}

Table A3: Number of responses and non-responses, by industry.

\begin{tabular}{l|ccccc|c} 
Industry & Answered & $\begin{array}{c}\text { Not } \\
\text { found }\end{array}$ & $\begin{array}{c}\text { Did not } \\
\text { answer }\end{array}$ & Bankruptcy & $\begin{array}{c}\text { Other } \\
\text { reasons }\end{array}$ & Total \\
\hline Manufacturing & 956 & 485 & 432 & 24 & 28 & 1925 \\
Construction & 121 & 75 & 50 & 6 & 7 & 259 \\
Trade & 329 & 214 & 102 & 15 & 12 & 672 \\
Transport & 153 & 83 & 41 & 2 & 7 & 286 \\
Services & 402 & 261 & 106 & 18 & 12 & 799 \\
\hline Total & 1961 & 1118 & 731 & 65 & 66 & 3941
\end{tabular}

Table A4: Number of responses and non-responses, by firm size.

\begin{tabular}{l|ccccc|c} 
Firm size & Answered & $\begin{array}{c}\text { Not } \\
\text { found }\end{array}$ & $\begin{array}{c}\text { Did not } \\
\text { answer }\end{array}$ & Bankruptcy & $\begin{array}{c}\text { Other } \\
\text { reasons }\end{array}$ & Total \\
\hline 20-29 employees & 329 & 161 & 184 & 13 & 11 & 698 \\
30-39 employees & 225 & 115 & 88 & 10 & 4 & 442 \\
40-49 employees & 166 & 73 & 61 & 3 & 5 & 308 \\
50-99 employees & 607 & 295 & 216 & 19 & 19 & 1156 \\
100+ employees & 634 & 474 & 182 & 20 & 27 & 1337 \\
\hline Total & 1961 & 1118 & 731 & 65 & 66 & 3941
\end{tabular}


TableA5: Number of firms and rate of coverage for industries.

\begin{tabular}{l|ccc} 
Industry & $\begin{array}{c}\text { All firms }>20 \\
\text { employees }\end{array}$ & Answered & \% answered \\
\hline Manufacturing & 1939 & 956 & 49.3 \\
Construction & 1036 & 121 & 11.7 \\
Trade & 2242 & 329 & 14.7 \\
Transport & 883 & 153 & 17.3 \\
Services & 2200 & 402 & 18.3 \\
\hline Total & 8300 & 1961 & 23.6
\end{tabular}

Table A6: Number of firms and rate of coverage for size groups.

\begin{tabular}{l|ccc} 
Firm size & $\begin{array}{c}\text { All firms }>20 \\
\text { employees }\end{array}$ & Answered & \% answered \\
\hline 20-29 employees & 3035 & 329 & 10.8 \\
$30-39$ employees & 1435 & 225 & 15.7 \\
$40-49$ employees & 874 & 166 & 19.0 \\
$50-99$ employees & 1602 & 607 & 52.5 \\
$100+$ employees & 1354 & 634 & 46.8 \\
\hline Total & 8300 & 1961 & 23.6
\end{tabular}

\section{B. Job destruction in Denmark during the crisis}

Table B1 shows that Denmark has lost almost $9 \%$ of all private sector jobs since the $3^{\text {rd }}$ quarter of 2008. The largest loss was in the Manufacturing industry with $15 \%$ of all jobs. Manufacturing was most vulnerable because of a wage growth higher than in countries competing with Danish products, especially Germany, (DA, 2012). Since the ECB survey was conducted in the summer of 2009 and the Danish survey was run in Nov-Dec 2011, it is obvious that Denmark was surveyed later in the development of the crisis and this will have an impact on the answers. First of all, it means that many adjustments have been executed in the early phase of the crisis, therefore making comparisons with the ECB survey difficult. Secondly, a number of the Danish firms might have left the sample of firms surveyed because they have lost many jobs already or might have gone bankrupt at the time of our survey. Table B1 shows that $3 / 4$ of the job destruction happened in the first phase of the crisis, from the $3^{\text {rd }}$ quarter of 2008 to the second quarter of 2009, when the ECB survey was conducted. Conversely, $1 / 4$ of the total destruction happened between the time of the ECB-survey and our survey. Thus, it is most likely that the firms are more influenced by the second phase of the crisis than by the first phase, when responding to the survey. 
Table B1: Total job destruction in the Private sector from 2008.

\begin{tabular}{|c|c|c|c|c|c|c|c|}
\hline Job loss in & $\mathrm{Q}_{3}{ }^{2008}$ & $\begin{array}{l}\text { Overall } \\
\left(\mathrm{Q}_{2}^{2008}-\right. \\
\left.\mathrm{Q}_{3}^{2011}\right)\end{array}$ & $\begin{array}{l}\text { The first } \\
\text { phase } \\
\left(\mathrm{Q}_{2}^{2008}{ }^{2009}\right. \\
\left.\mathrm{Q}_{3}{ }^{2009}\right)\end{array}$ & $\begin{array}{l}\text { The } \\
\text { second } \\
\text { phase } \\
\left(\mathrm{Q}_{3}{ }^{2009}-\right. \\
\left.\mathrm{Q}_{3}{ }^{2011}\right)\end{array}$ & $\begin{array}{l}\text { Impact } \\
\text { in the } \\
\text { First } \\
\text { phase } \\
(\%)\end{array}$ & $\begin{array}{l}\text { Impact } \\
\text { in the } \\
\text { Second } \\
\text { phase } \\
(\%)\end{array}$ & $\begin{array}{l}\text { Overall } \\
\text { change } \\
(\%) \\
\left(Q_{3}{ }^{2008}-\right. \\
\left.Q_{3}{ }^{2011}\right)\end{array}$ \\
\hline $\begin{array}{l}\text { Manufacturing, } \\
\text { mining and } \\
\text { quar. }\end{array}$ & 427651 & -67358 & -47446 & -25052 & 70 & 30 & -15.8 \\
\hline Construction & 212560 & -26762 & -20155 & -7807 & 75 & 25 & -12.6 \\
\hline $\begin{array}{l}\text { Trade and } \\
\text { transport etc. }\end{array}$ & 787168 & -48659 & -36269 & -15946 & 75 & 25 & -6.2 \\
\hline $\begin{array}{l}\text { antormation } \\
\text { and } \\
\text { communication }\end{array}$ & 115620 & -6515 & -3709 & -2128 & 57 & 43 & -5.6 \\
\hline $\begin{array}{l}\text { Financial and } \\
\text { insurance }\end{array}$ & 96028 & -7433 & -5484 & -2707 & 74 & 26 & -7.7 \\
\hline Real estate & 64140 & -1023 & -4418 & 1566 & 432 & -332 & -1.6 \\
\hline $\begin{array}{l}\text { Other business } \\
\text { services }\end{array}$ & 332871 & -23829 & -18248 & -6795 & 77 & 23 & -7.2 \\
\hline Total & 2036038 & -181579 & -135729 & -58869 & 75 & 25 & -8.9 \\
\hline
\end{tabular}

Figure B1 shows the evolution of jobs in Denmark in the past 5 years and the differences between the effects captured by our survey and the ECB survey.

Figure A1. Evolution of jobs in main private industries, 2007-2011.

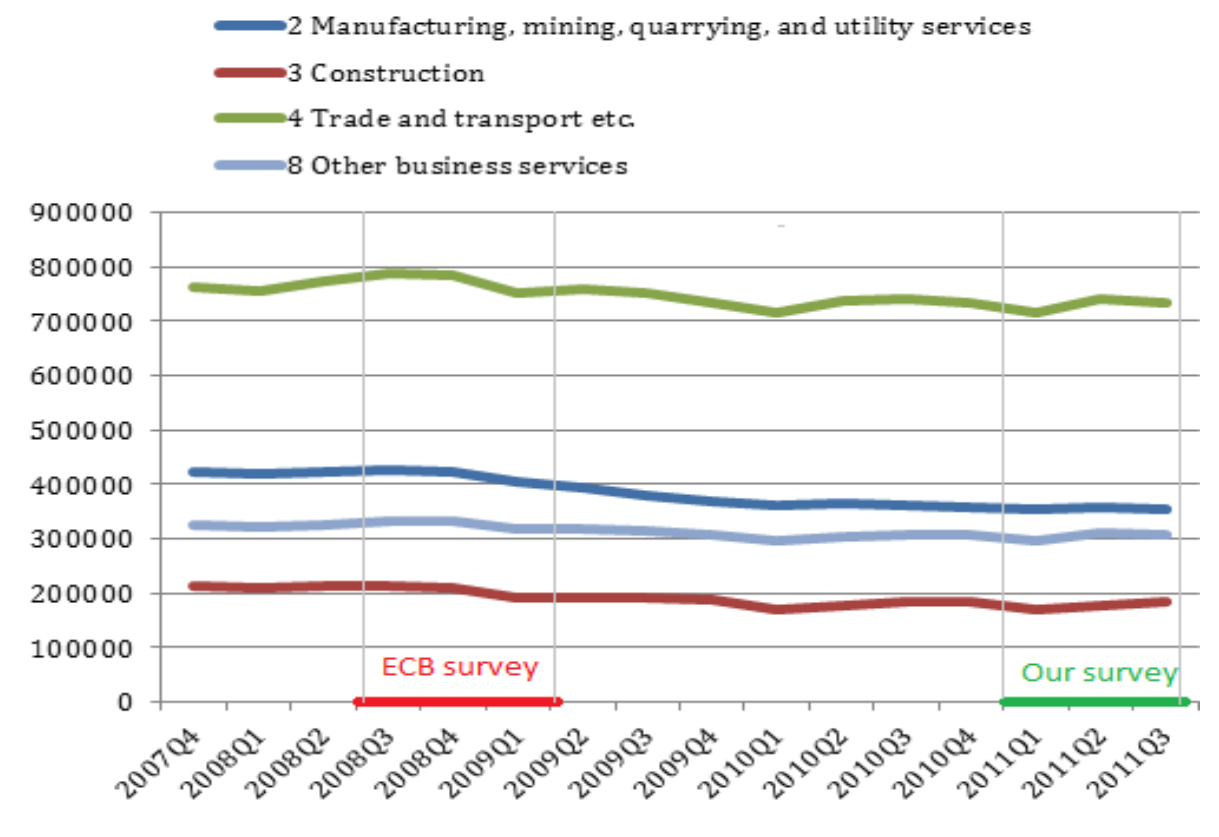




\section{The Questionnaire}

\section{Questions on the reaction to the current economic downturn}

1 - To what extent is your firm's activity (in terms of turnover) affected by the current economic and financial crisis?

Please choose a single option

$\square$ Negatively affected (please specify) anot at all amarginally amoderately $\quad$ astrongly $\quad$ cexceptionally

$\square$ Positively affected

$\square$ Not at all

2 - To what extent is the current economic and financial crisis affecting your firm with respect to each of the following aspects? Please choose an option for each line

\begin{tabular}{|c|c|c|c|c|c|}
\hline & not at all & marginally & moderately & strongly & $\begin{array}{l}\text { exceptionally } \\
\text { strongly }\end{array}$ \\
\hline $\begin{array}{l}\text { Fall in the demand for your firm's } \\
\text { products/services }\end{array}$ & $\square$ & $\square$ & $\square$ & $\square$ & $\square$ \\
\hline $\begin{array}{l}\text { Difficulty in financing your firm's activity } \\
\text { through the usual financial channels }\end{array}$ & $\square$ & $\square$ & $\square$ & $\square$ & $\square$ \\
\hline Difficulty in being paid by customers & $\square$ & $\square$ & $\square$ & $\square$ & $\square$ \\
\hline $\begin{array}{l}\text { Difficulty in obtaining intermediate products } \\
\text { from your firm's usual suppliers }\end{array}$ & $\square$ & $\square$ & $\square$ & $\square$ & $\square$ \\
\hline
\end{tabular}

3 - If the current economic and financial crisis is causing a fall in the demand for your firm's products/services, to which degree has your company adopted each of these strategies to face such a fall? Please choose an option for each line

\begin{tabular}{l|llll} 
& Toa high degree & To some degree & To a low degree & Not at all \\
\hline Reduce prices & $\square$ & $\square$ & $\square$ & $\square$ \\
Reduce margins & $\square$ & $\square$ & $\square$ & $\square$ \\
Reduce output & $\square$ & $\square$ & $\square$ & $\square$ \\
Reduce costs & $\square$ & $\square$ & $\square$ & $\square$
\end{tabular}

4 - If the reduction of costs is of any relevance in your answer to question 3, please indicate the main channel through which this goal is achieved in your firm.

Please choose a single option, the most important factor

Reduce base wages

Reduce flexible wage components

(for example bonuses, benefits, etc.)

Reduce the number of permanent employees

Adjust the number of hours worked per employee

Reduce other costs

5 - In the current economic and financial crisis, has your firm (or is it going to) frozen the base wage of some employees?

Freeze in base wage: base wage in nominal terms is unchanged from one pay negotiation to the next The last two options are not mutually exclusive

No

Yes we froze the nominal base wage

For what percentage of employees

Yes we are going to freeze the nominal base wage 
6 - In the current economic and financial crisis, has your firm (or is it going to) cut the base wage of some employees?

Cut in base wage: base wage in nominal terms is decreased from one pay negotiation to the next

The last two options are not mutually exclusive

No

Yes we froze the nominal base wage

For what percentage of employees

Yes we are going to freeze the nominal base wage

7 - If the current economic situation is causing financial difficulties for your firm, please indicate the reason for this.

The options are not mutually exclusive

The bank has limited an existing credit

The bank is unwilling to expand current credit line

Borrowing costs have become too high

\section{Questions on other economic factors}

8 - Does your firm have any of the following bonus systems for each of the following employees groups?

\begin{tabular}{|c|c|c|c|c|c|c|}
\hline & $\begin{array}{l}\text { Individual } \\
\text { bonuses }\end{array}$ & $\begin{array}{l}\text { Team } \\
\text { bonuses }\end{array}$ & $\begin{array}{l}\text { Stocksor } \\
\text { warrants }\end{array}$ & $\begin{array}{l}\text { Equities } \\
\text { Employee } \\
\text { shares }\end{array}$ & $\begin{array}{l}\text { Profit } \\
\text { shares }\end{array}$ & $\begin{array}{l}\text { Qualificati } \\
\text { on based } \\
\text { wages }\end{array}$ \\
\hline $\begin{array}{l}\text { Top-management } \\
\text { personnel }\end{array}$ & $\square$ & $\square$ & $\square$ & $\square$ & $\square$ & $\square$ \\
\hline $\begin{array}{l}\text { Mid-level management } \\
\text { personnel }\end{array}$ & $\square$ & $\square$ & $\square$ & $\square$ & $\square$ & $\square$ \\
\hline Salaried employees & $\square$ & $\square$ & $\square$ & $\square$ & $\square$ & $\square$ \\
\hline Workers & $\square$ & $\square$ & $\square$ & $\square$ & $\square$ & $\square$ \\
\hline
\end{tabular}

9 - Does your firm have any of the following characteristics:

Yes/No

Is covered by a collective agreement for monthly paid (salaried) employees

Yes/No

Is covered by a collective agreement for hourly paid employees (workers)

Yes/No

Has a collective contract that makes it possible to work flexible hours without overtime pay

Yes/No

For salaried employees

Yes/No

For workers

The firm is a subsidiary of a firm abroad

Yes/No

Yes/No

The firm is a parent company for one or more companies abroad

Yes/No

The firm has created jobs in 2011

Yes/No

The firm has destroyed jobs in 2011

Yes/No

10 - How many competitors does your firm have in the market of your core business? $\quad(0 \ldots 1000)$

11 - How big is the increase in turnover in 2011 compared to 2010? (percentages) 